\title{
KAJIAN PENERAPAN AKUNTANSI SUMBER DAYA MANUSIA TERHADAP LAPORAN LABA RUGI DAN NERACA DI PT. BPR SINDANG BINAHARTA KOTA LUBUKLINGGAU
}

\author{
Eri Triharyati ${ }^{1}$ \\ E-mail : 3triharyati@gmail.com \\ Emma Nursita ${ }^{2}$ \\ E-mail : emmanursita.15.10@gmail.com
}

\section{UNIVERSITAS BINA INSAN LUBUKLINGGAU}

\begin{abstract}
This study aims to the study of the application of Human Resource Accounting to the Profit Loss and Balance Sheet at PT. BPR Sindang Binaharta Lubuklinggau City. The study application of Human Resource Accounting could be seen by the recording conducted by PT. BPR Sindang Binaharta Lubuklinggau City releted to the cost human resource (education and training ). Method used in this research is to use descriptive research type, by comparing profit loss and balance sheet before and after the application of Human Resource Accounting. Based on the research, will show those Human Resource Accounting concept giving a bigger net income to income statement. This is raising because cost education and training already in amortisasi and this cost avowed as asset in company. On the balance sheet based on Convensional Accounting and Human Resource Accounting will also showed the raising.This is raising because cost education and training as avowed asset in company.
\end{abstract}

\section{Keywords : Human Resource Accounting, Profit Loss and Balance Sheet}

\section{PENDAHULUAN}

Di era globalisasi yang diiringi dengan kemajuan tekhnologi canggih, maka dunia usaha mau tidak mau didorong untuk mencapai suatu organisasi perusahaan yang efektif dan efisien agar mampu bertahan dan bersaing dengan perusahaan-perusahaan yang lainnya. Keefektifan dan keefisienan dalam suatu perusahaan harus memiliki daya saing maupun keunggulan yang lebih dari pada pesaing, sehingga perusahaan dapat bertahan dalam dunia global dan persaingan yang ketat. Begitu juga untuk menghadapi persaingan sekarang harus memiliki sumber daya manusia yang berkualitas.

PT. BPR Sindang Binaharta Kota Lubuklinggau merupakan lembaga perbankan yang kegiatan utamanya adalah menghimpun dana masyarakat dalam bentuk tabungan dan deposito berjangka dan menyalurkan kembali ke masyarakat dalam bentuk pinjaman 
atau kredit jangka pendek. PT BPR Sindang Binaharta Kota Lubuklinggau selama ini masih menggunakan akuntansi konvensional yang mencatat atau memperlakukan dana yang telah dikeluarkan perusahaan untuk pembiayaan sumber daya yang dimilikinya sebagai biaya atau beban bukan sebagai aset. Daftar biaya Sumber Daya Manusia di PT. BPR Sindang Binaharta Kota Lubuklinggau Tahun 2016 - 2018 dapat dilihat pada tabel dibawah ini :

Tabel 1

Biaya Sumber Daya

\begin{tabular}{ccc}
\hline No & Tahun & Biaya Pendidikan dan Pelatihan \\
\hline 1 & 2016 & Rp. 85,147,250 \\
2 & 2017 & Rp. 97,433,520 \\
3 & 2018 & Rp. 102,906,307 \\
\hline
\end{tabular}

Sumber : PT. BPR Sindang Binaharta Kota Lubuklinggau

Berdasarkan tabel diatas kita dapat melihat bahwa biaya pendidikan dan pelatihan pada tahun 2016 adalah sebesar Rp. 85,147,250 di tahun 2017 adalah sebesar Rp. 97,433,520 dan ditahun 2018 adalah sebesar Rp.102,906,307. Setiap tahunnya biaya pendidikan dan pelatihan ini terus meningkat. Konsep Akuntansi Sumber Daya Manusia, beban pendidikan dan pelatihan yang telah dikeluarkan oleh perusahaan dikeluarkan dari biaya Sumber Daya Manusia sehingga mengurangi beban usaha sehingga akan meningkatkan laba bersih yang didapat perusahaan dalam tahun buku tersebut. PT BPR Sindang Binaharta dalam kegiatannya pasti akan membutuhkan tenaga - tenaga yang handal yang perlu dalam penerapan Akuntansi Sumber Daya Manusia dengan konsep pelatihan dan pendidikan bagi karyawannya.

Berdasarkan uraian diatas, maka peneliti tertarik untuk melakukan penelitian dengan judul “ Kajian Penerapan Akuntansi Sumber Daya Manusia terhadap Laporan Laba Rugi dan Neraca di PT. BPR Sindang Bina Harta Kota Lubuklinggau.

\section{TINJAUAN PUSTAKA}

\section{Defenisi, Fungsi Dan Tujuan Akuntansi Sumber Daya Manusia}

Menurut Agus ( 2013 : 03 ) mengatakan bahwa akuntansi sumber daya manusia adalah proses mencakup pengidentifikasian dan pengukuran biaya yang dikeluarkan untuk aktiva manusia, mencakup biaya untuk merekrut, memperkerjakan, melatih dan mengembangkan aktiva manusia. Menurut Hariyanto ( 2013 : 02 ) dalam jurnal Astri, dkk (2017:02) Akuntansi Sumber Daya Manusia adalah suatu pengakuan bahwa orangorang merupakan modal manusia maupun aktiva manusia.

Menurut Yunus ( 2017 : 227 ) prinsip - prinsip dasar Akuntansi Sumber Daya Manusia memiliki tiga elemen utama yaitu : 


\section{Human Capital ( modal manusia )}

Human Capital mencerminkan kemampuan kolektif perusahaan untuk menghasilkan solusi terbaik berdasarkan pengetahuan yang dimiliki oleh orang orang yang ada dalam perusahaan tersebut.

2. Stuctural Capital atau Organizational ( modal organisasi )

Stuctural Capital merupakan kemampuan organisassi atau perusahaan dalam memenuhi proses rutinitas perusahaan dan strukturnya yang mendukung usaha karyawan untuk menghasilkan kinerja intelektual yang optimal serta kinerja bisnis secara keseluuhan.

3. Relational Capital atau Customer Capital (modal pelanggan)

Elemen ini merupakan komponen intelektual yang memberikan nilai secara nyata.

Menurut Agus ( 2013 : 5 ) ada 2 prinsip yang perlu diperhatian dalam Akuntansi Sumber Daya Manusia, yaitu :

1. Sumber Daya Manusia sebagai asset atau aktiva, yang harus dicantumkan dalam Neraca, dan

2. Bagian dari biaya Sumber Daya Manusia yang dikaitkan dengan pendapatan dalam suatu periode akuntansi (dimasukkan dalam laporan Laba / Rugi).

\section{Fungsi dan Tujuan Akuntansi Sumber Daya Manusia}

Menurut Harahap ( 2003) dalam Junal Rizky dan Devi (2018 : 93) secara umum fungsi Akuntansi Sumber Daya Manusia :

1. Untuk melengkapi informasi tentang nilai SDM untuk pengambilan keputusan tentang perolehan, alokasi, pembangunan, pemeliharaan SDM agar tercapai efektivitas tujuan organisasi.

2. Untuk memberrikan informasi kepada manajer personalia agar dia dapat secara efektif memonitor dan menggunakan SDM.

3. Memberikan indikator dalam pengawasan Aktiva. Misalnya apakah aktiva ini dipertahankan, dijual atau dinaikkan, berapakah nilainya, apakah nilai sumber daya ini bekurang atau naik selama suatu periode tertentu.

4. Membantu pengembangan prinsip manajemen dengan menjelasskan akibat keuangan dari berbagai praktek Akuntansi Sumber Daya Manusia.

Menurut Belkaoui ( 1995 ) dalam jurnal Yunus ( 2016 : 227 ) Fungsi dan Tujuan Akuntansi Sumber Daya Manusia adalah sebaga berikut :

1. Mengidentifikasi nilai sumber daya manusia

2. Mengukur biaya dan nilai manusia yang dikontribusikan kepada perusahaan

3. Mengkaji pengaruh pemahaman informasi ini dan dampaknya pada perilaku manusia 
Menurut Ikhsan ( 2008 : 67 ) Fungsi dan Tujuan Sumber daya Manusia yaitu:

1. Menyediakan kerangka kerja untuk membantu manajer dalam menggunakan sumber daya manusia secara efektif dan efesien.

2. Menyediakan informasi yang dibutuhkan bagi pengguna dalam memperoleh, mengembangkan, menempatkan, mengkonversi, menggunakan, mengevaluasi, dan menghargai sumber daya manusia

3. Menyediakan alat pengukur biaya dan nilai dari manusia bagi organisasi untuk digunakan dalam pengambil keputusan

4. Memotivasi manajer untuk menghargai akibat pengambilan keputusan usaha atas sumber daya manusia

Berdasarkan penjelasan diatas maka disimpulkan fungsi dan tujuan dari akuntansi sumber daya manusia adalah untuk mengidentifikasi, mengukur dan memberikan informasi dalam pengambilan keputusan. Menurut Warno ( 2011 : 10 ) untuk mengetahui tahapan dalam penerapan akuntansi sumber daya manusia dapat dilihat dari:

1. Sebagai investasi masa panjang pada neraca dan diamortisasikan sesuai dengan masa manfaat. Posisi di neraca sebelah debet jika penambahan dan di sebalah kredit jika pengurangan.

2. Sebagai aktiva tak berwujud yang tidak langsung diakui sebagai goodwill dan kemudia bediri sendiri. Posisi di neraca sebelah debet jika penambahan dan di sebalah kredit jika pengurangan.

3. Diperlakukan sebagai beban yang ditangguhkan dalam akuntansi konvensional.

4. Dalam hal penangguhan biaya penelitian dan pengembangan karyawan

Menurut Ikhsan ( 2008 : 182-184 ) untuk mengetahui penerapan akuntansi sumber daya manusia ada beberapa tahapan yang harus dilakukan :

1. Mengukur biaya sumber daya manusia

2. Mengukur nilai sumber daya manusia

3. Pengukuran nilai manusia non moneter

Hal ini didasarkan pada ketentuan bahwa nilai seseorang merupakan hasil kontribusi terhadap suatu organisasi (seperti sifat-sifat, keterampilan, dan motivasi) serta karakteristik organisasi itu sendiri (seperti struktur, sistem penghargaan, gaya manajemen dan pembagian peran).

4. Pengukuran moneter atas nilai manusia yaitu sebagian diantaranya ditunjukan untuk mengukur nilai manusia secara langsung, sedangkan teknik - teknik lainnya sebagai ukuran proksi.

Berdasarkan penjelasan diatas dapat disempulkan bahwa tahapan dalam akuntansi sumber daya manusia adalah sebagai pengukur biaya dan nilai sumber daya manusia 
dan pengukuran nonmoneter serta moneter atas nilai manusia yang bisa dilihat dalam neraca dan laporan laba rugi.

\section{1) Pengertian Laporan Laba Rugi}

Menurut Sugiono ( 2016 : 21 ) Laporan Laba Rugi adalah laporan ringkas tentang jenis dan jumlah pendapatan atau hasil penjualan yang diperoleh perusahaan selama periode tertentu, biaya selama masa itu dan keuntungan atau kerugian yang diderita selama periode tertentu ( misalnya; satu bulan, perkuartal, pertahun, dsb ). Menurut Sujarweni ( 2017 : 13 ) Laporan Laba Rugi adalah laporan yang disusun sistematis, isinya penghasilan utang diperoleh perusahaan dikurangi dengan beban - beban yang terjadi dalam perusahaan selama periode tertentu. Menurut Kasmir ( 2017 : 29 ) Laporan Laba Rugi ( income statement ) merupakan laporan keuangan yang menggambarkan hasil usaha perusahaan dalam suatu periode tertentu.

Berdasarkan penjelasan diatas maka Laporan Laba Rugi adalah bentuk laporan keuangan yang menyajikan biaya, beban dan pendapatan dalam periode tertentu.

\section{2) Pengertian Neraca}

Menurut Sugiono ( $2016: 13$ ) Neraca adalah suatu laporan yang sistematis tentang ( assets ), kewajiban ( liabilities ), dan modal sendiri ( equity) dari suatu perusahaan pada tanggal / waktu tertentu atau dengan kata lain Neraca berisi mengenai data-data informasi mengenai kondisi perusahaan pada waktu tertentu.

Menurut Sujarweni ( 2017 : 20 ) Neraca adalah laporan yang menggambarkan posisi keuangan suatu perusahaan yang meliputi aktiva, kewajiban, dan ekuitas pada periode tertentu. Menurut Kasmir ( 2017 : 30 ) Neraca adalah salah satu laporan yang paling terpenting bagi perusahaan. Oleh setiap perusahaan diharuskan untuk menyajikan laporan keuangan dalam bentuk neraca. Neraca biasanya disusun pada periode tertentu, misalnya satu tahun. Namun, neraca juga dapat dibuat saat ini bila diperbolehkan. Biasanya hal ini sering dilakukan pihak manjemen pada periode tertentu.

Berdasarkan penjelasan diatas maka dapat disimpulkan bahwa neraca adalah sebuah bentuk laporan keuangan yang penting dalam suatu perusahaan dan neraca juga merupakan suatu ringkasan dalam laporan keuangan. Laporan keuangan yang disusun secara garis besarnya saja dan tidak mendetail. Neraca menunjukkan posisi keuangan berupa aktiva (harta ), kewajiban ( utang ), dan modal perusahaan ( ekuitas ) pada saat tertentu. Metode penelitian yang digunakan oleh peneliti adalah metode kualitatif untuk 
mengkaji penerapan akuntansi sumber daya manusia terhadap laporan keuangan dan neraca di PT. BPR Sindang Binaharta Kota Lubuklinggau.

\section{METODE PENELITIAN}

Data dan Sumber Data

Sumber data menurut Sugiono ( $2015: 245$ ) terbagi menjadi dua yaitu:

1. Data Primer adalah sumber data yang langsung memberikan data kepada pengumpul data.

2. Data Sekunder adalah data yang bersumber tidak langsung memberikan data kepada pengumpul data.

Berdasarkan pembagian data menurut sumber tersebut diatas maka dalam penelitian ini peniliti menggunakan data primer dan data sekunder. Data primer yang digunakan peneliti merupakan wawancara berupa tanya jawab langsung dengan HRD, Kepala Bagian Keuangan dan Kepala Bagian Umum yang berkaitan dengan pendidikan dan pelatihan. Data sekunder yang peneliti kumpulkan dari pihak internal PT. BPR Sindang Binaharta Kota Lubuklinggau yaitu gambaran umum tentang PT. BPR Sindang Binaharta Kota Lubuklinggau, data laporan laba rugi mengenai biaya sumber daya manusia dan data laporan neraca, serta data - data lainnya yang berhubungan dengan penelitian ini.

\section{Teknik dan Prosedur Pengumpulan Data}

Menurut Sugiono ( 2015 : 224 ) Teknik pengumpulan data merupakan langkah yang paling strategis dalam penelitian, karena tujuan utama dari penelitian adalah mendapatkan data. Adapun prosedur dalam pengumpulan data yang akan dilakukan yaitu :
a. Observasi
Observasi adalah pengamatan dan pencatatan secara sistematik terhadap suatu gejala yang tampak pada objek penelitian.
b. Wawancara
Wawancara adalah metode pengambilan data dengan cara menanyakan sesuatu kepada seseorang responden, caranya adalah dengan bercakap - cakap secara tata muka.
c. Dokumentasi
Dokumtansi adalah setiap catatan tertulis lalu, yang berhubungan dengan suatu peristiwa masa lalu, baik yang dipersiapkan maupun tidak dipersiapkan untuk suatu penelitian.

Berdasarkan dari penjelasan ini, maka peneliti menggunakan pengumpulan data dengan observasi, wawancara dan dokumentasi 


\section{HASIL PENELITIAN DAN PEMBAHASAN \\ Hasil Penelitian}

Berdasarkan Keputusan Presiden Republik Indonesia Nomor 38 Tahun 1988 Tentang

Bank Perkreditan Rakyat dan Keputusan Menteri Keuangan Nomor 1064/KMK.00/1988 Tahun 1988 Tentang Pendirian dan Usaha PT. BANK PERKREDITAN RAKYAT merupakan Lembaga perbankan yang kegiatan utamanya adalah menghimpun dana dari masyarakat dalam bentuk tabungan dan deposito berjangka dan menyalurkannya kembali ke masyarakat dalam bentuk pinjaman atau kredit jangka pendek.

PT. BPR Sindang Binaharta yang berkantor pusat di Jalan Sultan Mahmud badaruddin II KM.8 No 70 RT 05 Kelurahan Marga Rahayu Kecamatan Lubuklinggau Selatan II Kota Lubuklinggau yang didirikan dengan Akta Notaris No.53 Tanggal 30 Desember 1992 atas nama perusahaan PT. BPR Sindang Artha Kencana dan disahkan berdasarkan Surat Keputusan Menteri Kehakiman Republik Indonesia No. 02-1708 HT.01.01.Th93 Tanggal 18 Maret 1993. Pada tahun 1994 terdapat perubahan nama perusahaan sesuai dengan Akta Notaris No. 76 Tanggal 31 Agustus 1994 atas nama PT. BPR Sindang Binaharta disahkan izin usaha berdasarkan Surat Keputusan Menteri Keuangan Republik Indonesia Nomor Kep-325/KM.17/1994 Tanggal 16 November 1994 disahkan berdasarkan Keputusan Menteri Hukum dan Hak Azazi Manusia No. AHU44281. AH.01.02 tanggal 23 Agustus 2013 dan perubahan yang terakhir termaksud dalam Akta Notaris No.23 tanggal 14 Maret 2016. Seiring berjalannya waktu maka pada Tahun 2012 PT. BPR Sindang Binaharta membuka kantor kas di Jalan Yos Sudarso No.37 RT.11 Kelurahan Taba Jemekeh Kecamatan Lubuklinggau Timur I Kota Lubuklinggau. PT. BPR Sindang Binaharta dalam kegiatannya menghimpun dana dari masyarakat dalam bentuk Simpanan ( Tabungan / Deposito ) dan menyalurkan kembali dana tersebut kepada masyarakat dalam bentuk Kredit.

Penelitian ini dilakukan di PT. BPR Sindang Binaharta Kota Lubuklinggau yang pada kegiatannya menghimpun dana dari masyarakat dalam bentuk Simpanan ( Tabungan / Deposito ) dan menyalurkan kembali dana tersebut kepada masyarakat dalam bentuk Kredit. PT. BPR Sindang Binaharta Kota Lubuklinggau selama ini masih menggunakan Akuntansi Konvesional yang dimana biaya - biaya sumber daya manusia masih di akui sebagai beban bukan di akui sebagai aset.

Hal ini terlihat pada tabel 2 Laporan Laba Rugi pada tahun buku 2016 - 2018. Jika dikaji lebih mendalam berdasarkan konsep Akuntansi Sumber Daya Manusia, penyajian laporan Laba Rugi dan Neraca PT. BPR Sindang Binaharta Kota Lubuklinggau masih memiliki kelemahan. Letak kelemahan dalam penyajian laporan tersebut adalah belum realitis mengenai sumber daya manusia yang dimiliki perusahaan, karena selama ini PT. BPR Sindang Binaharta Kota Lubuklinggau telah melakukan investasi yang cukup 
besar untuk menggembangkan sumber daya manusia. Adapun jumlah investasi dalam sumber daya manusia dapat dilihat pada tabel 4.3 berikut :

Tabel 2

Biaya Sumber Daya Manusia

\begin{tabular}{ccc}
\hline No & Tahun & Biaya Pendidikan dan Pelatihan \\
\hline 1 & 2016 & Rp. $85,147,250$ \\
2 & 2017 & Rp. $97,433,520$ \\
3 & 2018 & Rp. 102,906,307 \\
\hline
\end{tabular}

Sumber Laporan Laba Rugi ( SDM ) PT. BPR Sindang Binaharta Kota

\section{Lubuklinggau}

Berdasarkan tabel 2 menunjukkan bahwa biaya sumber daya manusia tahun 2016 adalah sebesar Rp.85,147,250 di tahun 2017 adalah sebesar Rp.97,433,520 dan ditahun 2018 adalah sebesar Rp.102,906,307 biaya sumber daya manusia ini masih di akui sebagai beban pada laporan laba rugi di PT. BPR Sindang Binaharta Kota Lubuklinggau.

Tabel 3

Investasi Sumber Daya Manusia di PT. BPR Sindang Binaharta Kota Lubuklinggau

\begin{tabular}{cccc} 
Kegiatan & \multicolumn{3}{c}{ Tahun } \\
\cline { 2 - 4 } Investasi & $\mathbf{2 0 1 6}$ & $\mathbf{2 0 1 7}$ & $\mathbf{2 0 1 8}$ \\
\hline Pendidikan dan & Rp. 28,382,417 & Rp. 32,477,840 & Rp.34,302,102 \\
Pelatihan & & & \\
\hline
\end{tabular}

Sumber : Berdasarkan data yang telah diolah peneliti

Berdasarkan tabel 3 Peneliti telah mengola / menghitung sumber daya manusia PT. BPR Sindang Binaharta Kota Lubuklinggau dengan menggunakan konsep Akuntansi Sumber Daya Manusia dan mengamortisasikan biaya pendidikan dan pelatihan pada tabel 2, setelah melakukan perhitungan ini di dapatkan hasil Investasi Sumber Daya Manusia pada tahun 2016 adalah sebesar Rp. 28,382,417 tahun 2017 adalah sebesar Rp. 32,477,840 dan tahun 2018 adalah sebesar Rp.34,302,102. Biaya Investasi Sumber Daya Manusia ini akan dimasukan kedalam laporan laba rugi dengan akun amortisasi sumber daya manusia. Pada laporan neraca biaya pendidikan dan pelatihan tahun 2016 sebesar Rp.85,147,250 tahun 2017 sebesar Rp.97,433,520 dan 2018 sebesar Rp.102,906,307 akan dicatat sebagai investasi sumber daya manusia serta diletakan dalam kelompok aktiva dan lain - lain. Pada Laporan Laba Rugi PT. BPR Sindang Binaharta Kota Lubuklinggau tidak menemukan adanya biaya amortisasi atas investasi dalam sumber daya manusia. Begitu pula dengan Laporan Neraca PT. BPR Sindang Binaharta Kota Lubuklinggau tidak mencantumkan berapa besar nilai investasi sumber 
daya manusia dalam periode yang bersangkutan. Hal ini menunjukkan bahwa perusahaan belum menerapkan konsep Akuntansi Sumber Daya Manusia. Kegiatan pendidikan dan pelatihan selalu diadakan setiap tahunnya dan jumlah biaya yang di keluarkan selalu meningkat. Peningkatan biaya sumber daya manusia setiap tahunnya dikarenakan pendidikan yang selalu juga meningkat, hal ini bisa terjadi biasanya dikarenakan ada kententuan Otoritas Jasa Keuangan (OJK) yang baru dan ada juga progam baru lainnya.

Pengeluaran yang cukup besar ini tidak seharusnya dibebankan secara langsung dalam satu periode akuntansi saja. Manfaat dari pengetahuan, keterampilan, dan pengalaman yang diperoleh dari program pendidikan dan pelatihan tersebut tidak hilang dalam satu periode saja bahkan dapat dinikmati perusahaan dalam periode berikutnya. Manfaat dari pelatihan dan pendidikan karyawan terasa lebih realitis apabila biaya tersebut diamortisasikan selama masa manfaat yang telah diperkiraan sebelumnya. Pembebanan secara langsung biaya pendidikan dan pelatihan karyawan pada suatu periode akan berakibat pada penurunan nilai laba bersih yang didapat perusahaan pada periode yang bersangkutan. Hal tersebut mempengaruhi nilai total aktiva pada periode yang bersangkutan yang cenderung tidak realitis karena tidak mengandung investasi dalam sumber daya manusia.

\section{PEMBAHASAN}

\section{a) Akuntansi Sumber Daya Manusia}

Berdasarkan konsep Akuntansi Sumber Daya Manusia dengan menggunakan metode pengukuran berdasarkan biaya dengan metode biaya historis dari biaya belajar. Biaya belajar ( Development Cost) merupakan biaya yang dikeluarkan PT. BPR Sindang Binaharta Kota Lubuklinggau untuk melatih dan mengembangkan ( pendidikan ) pegawai dengan tujuan untuk meningkatkan kualitas serta kemampuan pegawainya sehingga memiliki produktivitas yang tinggi. Data biaya SDM perusahaan tersebut adalah :

Tabel 4

Biaya Sumber Daya Manusia

\begin{tabular}{ccc}
\hline No & Tahun & $\begin{array}{c}\text { Biaya Pendidikan dan } \\
\text { Pelatihan }\end{array}$ \\
\hline 1 & 2016 & Rp. 85,147,250 \\
2 & 2017 & Rp. 97,433,520 \\
3 & 2018 & Rp. 102,906,307 \\
\hline
\end{tabular}

Sumber : PT. BPR Sindang Binaharta Kota Lubuklinggau

Menurut Akuntansi Sumber Daya Manusia, semua biaya tersebut dimasukkan sebagai aktiva SDM. Jurnal penyesuaian yang diperlukan adalah: 
Tahun 2016

Dr Aktiva Sumber Daya Manusia

Rp. 85,147,250

Cr Beban Pendidikan dan Pelatihan

Tahun 2017

Dr Aktiva Sumber Daya Manusia

Rp. 97,433,520

Cr Beban Pendidikan dan Pelatihan

Tahun 2018

Dr Aktiva Sumber Daya Manusia

Rp. 102,906,307

Cr Beban Pendidikan dan Pelatihan

Rp. 102,906,307

\section{Keterangan:}

Dr : Debere

$\mathrm{Cr}$ : Credere

\section{Amortisasi Akuntansi Sumber Daya Manusia}

Metode amortisasi garis lurus yang digunakan dalam penelitian ini mengikuti PSAK No. 19 Tahun 2009 yang menyatakan bahwa metode amortisasi aktiva tidak berwujud ( intagible asset ) adalah metode garis lurus.

Umur ekonomis mengikuti kebijakan manajemen aset sesuai PSAK No. 19 tahun 2009 tetapi karena penelitian ini adalah eksperimen maka mengikuti UU N0. 13 tahun 2003 tentang ketenagakerjaan yang menyatakan batas kontrak kerja selama 3 tahun, maka penelitian ini menggunakan umur ekonomis selama 3 tahun. Perhitungan amortisasi aset sumber daya manusia PT. BPR Sindang Binaharta Kota Lubuklinggu sebagai berikut :

\section{Tabel 5}

Amortisasi Aktiva SDM

\begin{tabular}{ccccc}
\hline $\begin{array}{c}\text { Biaya } \\
\text { Belaja } \\
\mathbf{r}\end{array}$ & $\begin{array}{c}\text { Jumlah Kotor } \\
\text { Aktiva SDM }\end{array}$ & $\begin{array}{c}\text { Umur } \\
\text { Manfaa } \\
\mathbf{t}\end{array}$ & $\begin{array}{c}\text { Amortisasi } \\
(\text { Rp) }\end{array}$ & $\begin{array}{c}\text { Jumlah Bersih } \\
\text { Atas SDM (Rp) }\end{array}$ \\
& & & & \\
2016 & Rp. 85,147,250 & 3 tahun & Rp. 28,382,417 & Rp. 28,382,417 \\
2017 & Rp. 97,433,520 & 3 tahun & Rp. 32, 477,840 & Rp. 32, 477,840 \\
2018 & Rp. 102,906,307 & 3 tahun & Rp. 34,302,102 & Rp. 34,302,102 \\
\hline
\end{tabular}

Sumber : Berdasarkan data yang telah diolah peneliti 
Jurnal yang diperlukan untuk amortisasi :

Tahun 2016

Dr Amortisasi aktiva sumber daya manusia

Rp. $28,382,417$

Cr Aktiva sumber daya manusia

Rp. $28,382,417$

\section{Tahun 2017}

Dr Amortisasi aktiva sumber daya manusia

Rp. $32,477,840$

Cr Aktiva sumber daya manusia

Rp. $32,477,840$

Tahun 2018

Dr Amortisasi aktiva sumber daya manusia

Cr Aktiva sumber daya manusia

Rp. $34,302,102$

Rp. 34,302,102

\section{Keterangan :}

Perhitungan Amortisasi selama 3 Tahun

1. Tahun 2016

$$
\begin{aligned}
& =\text { Rp. } 85,147,250 \\
& 3 \\
& =\text { Rp. } 28,382,417
\end{aligned}
$$

2. Tahun 2017

$$
\begin{aligned}
& =\text { Rp. } 97,433,520 \\
& 3 \\
& =\text { Rp. 32, 477, } 840
\end{aligned}
$$

\section{Tahun 2018}

$$
\begin{aligned}
& =\text { Rp. } 102,906,307 \\
& 3 \\
& =\text { Rp. } 34,302,102
\end{aligned}
$$

Jadi dari Amortisasi PT. BPR Sindang Binaharta Kota Lubuklinggau yang telah disajikan, menghasilkan jumlah investasi bersih atas SDM untuk tahun 2016 sebesar Rp. 28,382,417 tahun 2017 sebesar Rp.32,477,840 dan pada tahun 2018 sebesar Rp. 34,302,102. Berdasarkan konsep Akuntansi Sumber Daya Manusia, maka jumlah investasi bersih atas SDM tersebut di akui sebagai Amortisasi SDM dalam Laporan Laba Rugi perusahaan pada setiap akhir periode akuntansi dan diamortisasikan selama masa manfaat yang diperkirakan.

\section{Laporan Laba Rugi}

Laporan Laba Rugi merupakan salah satu laporan yang terdapat pada laporan keuangan. Laporan Laba Rugi erat kaitany dengan Akuntansi Sumber Daya Manusia karena pada laporan laba rugi dapat dilihat bahwa laporan tersebut sudah menerapkan Akuntansi Sumber Daya Manusia atau belum. Berdasarkan konsep Akuntansi Sumber Daya Manusia biaya-biaya yang dikeluarkan untuk investasi sumber daya manusia diakui sebagai aset bukan diakui sebagai beban. Beradasarkan perhitungan - perhitungan yang 
telah dilakukan didapat investasi pada aktiva SDM dan amortisasi aktiva SDM, serta investasi bersih pada aktiva SDM pada perusahaan tahun 2016 - 2018. Perlakuan Akuntansi Sumber Daya Manusia akan berpengaruh dalam laporan Laba Rugi perusahaan. Pada bagian ini peneliti akan mencoba menyajikan Akuntansi Sumber Daya Manusia dalam Laporan Laba Rugi dan kemudian membandingkannya dengan laporan Akuntansi Konvensional. Peneliti kemudian menganalisis perbandingan laporan Laba Rugi berdasarkan Akuntansi Konvensional yang diterapkan perusahaan dengan laporan Laba Rugi berdasarkan Akuntansi Sumber Daya Manusia.

Tabel 6

Perbandingan Laporan Laba Rugi

\begin{tabular}{cccc}
\hline $\begin{array}{c}\text { Laba } \\
\text { Bersih }\end{array}$ & $\begin{array}{c}\text { Akuntansi } \\
\text { Konvensional }\end{array}$ & $\begin{array}{c}\text { Akuntansi } \\
\text { SDM }\end{array}$ & Selisih \\
\hline 2016 & Rp. 290,414,000 & Rp. 347,179,000 & Rp. 56,765,000 \\
2017 & (Rp. 460,398,000) & (Rp. 395,442,000) & Rp. 64,956,000 \\
2018 & Rp. 203,791,000 & Rp. 272,395,000 & Rp. 68,604,000 \\
\hline
\end{tabular}

Berdasarkan hasil perbandingan antara laporan Laba Rugi Konvensional dengan laporan Laba Rugi Akuntansi Sumber Daya Manusia, menimbulkan selisih laba pada tahun 2016 sebesar Rp. 56,765,000 dan tahun 2018 Rp.68,604,000. Selisih laba yang cukup besar pada tahun 2016 dan 2018 ini dikarenakan pada laporan laba rugi biaya pendidikan dan pelatihan diamortisasikan dan ini sangat menguntungkan bagi pihak PT. BPR Sindang Binaharta Kota Lubuklinggau dengan menggunakan metode Akuntansi Sumber Daya Manuia. Pada tahun 2017 PT. BPR Sindang Binaharta Kota Lubuklinggau mengalami kerugian yang cukup besar yaitu (Rp. 460,398,000), ternyata dengan menggunakan perhitungan Akuntansi Sumber Daya Manusia kerugian yang didapatkan oleh PT. BPR Sindang Binaharta lebih kecil dibanding dengan menggunakan perhitungan Akuntansi Konvensional, selisih yang didapat dari perbandingan ini untuk kerugian tahun 2019 cukup besar yaitu sebesar Rp. 64,956,000. Dari uraian ini terlihat bahwa dengan penerapan Akuntansi Sumber Daya Manusia pada proses penyusunan laporan Laba Rugi perusahaan berpengaruh terhadap kenaikan laba bersih maupun penurunan nilai rugi yang diderita perusahaan pada tahun yang bersangkutan.

\section{Neraca}

Neraca merupakan salah satu laporan yang terdapat pada laporan keuangan. Erat kaitannya Akuntansi Sumber Daya Manusia dengan neraca karena dari neraca bisa terlihat bahwa perusahaan sudah menarapkan Akuntansi Sumber Daya Manusia atau 
belum, dalam Akuntansi Sumber Daya Manusia biaya-biaya yang dikeluarkan untuk sumber daya manusia disebut dengan investasi manusia dan diakui sebagai aset perusahaan. Beradasarkan perhitungan - perhitungan yang telah dilakukan didapat investasi pada aktiva SDM dan amortisasi aktiva SDM, serta investasi bersih pada aktiva SDM pada perusahaan tahun 2016 - 2018. Perlakuan Akuntansi Sumber Daya Manusia akan berpengaruh dalam laporan Neraca perusahaan. Pada bagian ini peneliti akan mencoba menyajikan Akuntansi Sumber Daya Manusia dalam Laporan Neraca dan kemudian membandingkannya dengan laporan Akuntansi Konvensional. Peneliti kemudian menganalisis perbandingan laporan Neraca berdasarkan Akuntansi Konvensional yang diterapkan perusahaan dengan laporan Neraca berdasarkan Akuntansi Sumber Daya Manusia.

\section{Tabel 7}

Perbandingan Neraca Tahun 2016

\begin{tabular}{cccc}
\hline Keterangan & $\begin{array}{c}\text { Akuntansi } \\
\text { konvensional }\end{array}$ & $\begin{array}{c}\text { Akuntansi } \\
\text { SDM }\end{array}$ & Selisih \\
\hline $\begin{array}{c}\text { Total Aktiva } \\
\begin{array}{c}\text { Total Kewajiban } \\
\text { dan Ekuitas }\end{array}\end{array}$ & Rp. $21,459,318,000$ & Rp. 21,544,465,000 & Rp. 85,147,000 \\
\hline
\end{tabular}

Sumber : Berdasarkan data yang telah diolah peneliti

Tabel 8

Perbandingan Neraca Tahun 2017

\begin{tabular}{cccc}
\hline Keterangan & $\begin{array}{c}\text { Akuntansi } \\
\text { konvensional }\end{array}$ & $\begin{array}{c}\text { Akuntansi } \\
\text { SDM }\end{array}$ & Selisih \\
\hline $\begin{array}{c}\text { Total Aktiva } \\
\begin{array}{c}\text { Total Kewajiban } \\
\text { dan Ekuitas }\end{array}\end{array}$ & Rp. 22,881,617,000 & Rp. 22,979,051,000 & Rp. 97,434,000 \\
\multicolumn{5}{c}{ Sumber : Berdasarkan data yang telah diolah peneliti } \\
Tabel 9 \\
Pp. 22,979,05,000 & Rp. 97,434,000 \\
\hline Keterangan & $\begin{array}{c}\text { Akuntansi } \\
\text { konvensional }\end{array}$ & $\begin{array}{c}\text { Akuntansi } \\
\text { SDM }\end{array}$ & Selisih \\
\hline $\begin{array}{c}\text { Total Aktiva } \\
\text { Total Kewajiban } \\
\text { dan Ekuitas }\end{array}$ & Rp. 21,255,781,000 & Rp. 21,358,687,000 & Rp. 102,906,000 \\
& Rp. 21, 255,781,000 & Rp. 21,358,687,000 & Rp. 102,906,000 \\
\hline
\end{tabular}

Sumber : Berdasarkan data yang telah diolah peneliti

Berdasarkan perbandingan neraca Akuntansi Konvensional dan Akuntansi Sumber Daya Manusia memiliki selisih yang cukup besar untuk total aktiva dan total kewajiban 
dan ekuitas selisih ini dikarenakan biaya pendidikan dan pelatihan dimasukan kedalam laporan neraca dan di akui sebagai Aset. Pada tahun 2016 terdapat selisih sebesar Rp 85,147,000 pada tahun 2017 sebesar Rp.97,434,000 dan tahun 2018 sebesar Rp.102,906,000. Adanya peningkatan jumlah aset dan ekuitas pada laporan neraca ini disebabkan jumlah investasi bersih sumber daya manusia yang terjadi pada setiap tahun yang ada, sehingga muncul akun baru aset sumber daya manusia pada posisi aset dan penyesuaian saldo laba pada posisi ekuitas.

\section{Kaitan Penelitian Relevan dengan Penelitian yang dilakukan Peneliti di PT. BPR Sindang Binaharta Kota Lubuklinggau.}

1. Menurut Yunus Fiscal, Desma Analisis Simulasi Penerapan Akuntansi Sumber Daya Manusia Terhadap Kinerja Keuangan (studi kasus pada PT. Bank Pembangunan Daerah Lampung Tahun 2012 -2014). Hasil perhitungan laba rugi dengan menggunakan akuntansi sumber daya manusia menghasilakan laba sebelum pajak lebih besar dibandingkan akuntansi konvensional pada tahun 2012 - 2014 ternyata hasil penelitian Yunus Fiscal dan Desma sama dengan Penelitian yang telah dilakukan peneliti di PT. BPR Sindang Binaharta Kota Lubuklinggau bahwasanya perhitungan laporan laba rugi dengan konsep Akuntansi SDM memiliki laba bersih yang lebih bersar dibandingkan dengan perhitungan Akuntansi Konvensional.

2. Heriston Sianturi, 2009 Analisis Penerapan Akuntansi Sumber Daya Manusia Terhadap Laporan Keuangan Pada PT. X. Hasil penelitian bahwa konsep akuntansi sumber daya manusia memberikan hasil laba bersih yang lebih besar pada laporan laba rugi. Dalam neraca berdasarkan akuntansi konvensional dan akuntansi sumber daya manusia terlihat pula bahwa dengan penerapan akuntansi sumber daya manusia, total aktiva meningkat. Ternyata hasil penelitian yang dilakukan oleh Heriston Sianturi sama dengan penelitian yang telah dilakukan peneliti di PT. BPR Sindang Binaharta Kota Lubuklinggau yaitu dengan menggunakan Konsep Akuntansi Sumber Daya Manusia perusahaan di PT. BPR Sindang Binaharta Kota Lubuklinggau memilki laba bersih yang lebih besar di laporan laba rugi dan pada laporan neraca total Aktiva meningkat.

3. Osomeke Monda, 2017 ternyata hasil penelitian Osomeke sama dengan penelitian yang dilakukan oleh peneliti di PT. BPR Sindang Binaharta Kota Lubuklinggau dimana dengan menerapkan Akuntansi Sumber Daya Manusia mendapatkan laba bersih yang lebih besar dibandingkan dengan menggunakan Akuntansi Konvensional dan dengan menggunakan Akuntansi SDM juga meningkatkan tota aktiva yg lebih besar.

Berdasarkan dari penjelasan ini dapat disimpulkan bahwa hasil penelitian relavan dengan hasil penelitian yang dilakukan peneliti di PT. BPR Sindang Binaharta Kota 
Lubuklinggau sama, ternyata dengan menerapkan Akuntansi Sumber Daya Manusia perusahaan akan mendapatkan laba bersih yang lebih besar dibandingkan dengan penerapan Akuntansi Konvensional. Total Aktiva pun meningkat dengan menggunakan Akuntansi Sumber Daya Manusia.

\section{KESIMPULAN}

Berdasarkan hasil penelitian dan pembahasan yang dilakukan maka peneliti menyimpulkan sebagai berikut : Kajian penerapan akuntansi sumber daya manusia terhadap laporan laba rugi dan neraca di PT. BPR Sindang Binaharta Kota Lubuklinggau bahwasanya belum menerapkan Akuntansi Sumber Daya Manusia, dimana biaya pendidikan dan pelatihan masih diakui sebagai beban bukan diakui sebagai aset perusahaan. Pengeluaran terhadap program pendidikan dan pelatihan karyawan di PT. BPR Sindang Binaharta Kota Lubuklinggau masih diperlakukan dengan menggunakan Akuntansi Konvensional. Pengeluaran itu masih diberlakukan sebagai beban dan langsung dihapuskan pada periode tersebut. Perbandingan laporan Laba Rugi PT. BPR Sindang Binaharta Kota Lubuklinggau pada tahun 2016 dan 2018 yang disajikan dengan menggunakan konsep Akuntansi Sumber Daya Manusia akan memperlihatkan laba bersih yang lebih besar pada laporan laba rugi, sedangkan pada tahun 2017 perusahaan mengalami kerugian yang cukup besar dimana dengan menggunakan perhitungan Akuntansi Sumber Daya Manusia memperlihatkan kerugian yang lebih kecil dibandingkan dengan menggunakan perhitungan Akuntansi Konvensional. Perbandingan neraca PT. BPR Sindang Binaharta Kota Lubuklinggau tahun 2016 - 2018 berdasarkan Akuntansi Konvensional dengan Akuntansi Sumber Daya Manusia terlihat pula bahwa dengan penerapan Akuntansi Sumber Daya Manusia, total aktiva yang ada meningkat.

\section{SARAN}

Berdasarkan kesimpulan yang telah disajikan, berikut ini disampaikan saran yang diharapkan dapat bermanfaat : Hendaknya penelitian ini bisa menjadi bahan pertimbangan kepada perusahaan untuk menggunakan metode Akuntansi Sumber Daya Manusia, dengan menggunakan metode Akuntansi Sumber Daya Manusia akan sangat menguntungkan bagi PT. BPR Sindang Binaharta Kota Lubuklinggau dikarenakan pada Laporan Laba Rugi biaya pendidikan dan pelatihan tidak lagi di akui sebagai beban tetapi biaya pendidikan dan pelatihan ini di akui sebagai Aset perusahaan dan akan dimasukkan ke dalam laporan neraca dengan akun Investasi Sumber Daya Manusia. Peneliti berharap adanya suatu standar Akuntansi Keuangan di Indonesia yang secara tegas dan khusus mengatur Akuntansi Sumber Daya Manusia dan penelitian ini diharapkan dapat memberi pengetahuan khususnyan tentang Akuntansi Sumber Daya Manusia.

\section{DAFTAR PUSTAKA}

Agus Hariyanto. 2013. Penerapan Akuntansi Sumber Daya Manusia dalam Laporan Keuangan. Dharma Ekonomi - STIE Dharmaputra. No. 37 / Th XX / April 2013. 
Dwi Maria, Siti Nurhayati, Jaka Darmawan. Penerapan Akuntansi Sumber Daya Manusia Terhadap Laporan Keuangan pada PT. Mensa Binasukses Palembang. Universitas Bina Darma.

Heriston Sianturi. 2009. Analisis Penerapan Akuntansi Sumber Daya Manusia Terhadap Laporan Keuangan. Jurnal Akuntansi Fakultas Ekonomi. Vol.2, No. 2, Desember 2009. Hal. 18-29.

Hery. 2015. Analisis Laporan Keuangan. Jakarta: CAPS

Ikhsan Arfan. 2008. Akuntansi Sumber Daya Manusia Suatu Tinjauan Penilaian Modal Manusia. Yogyakarta: Graha Ilmu.

Kasmir. 2017. Analisis Laporan Keuangan. Jakarta: Rajawali Pers

Mahmud, Halim Abdullah. 2016. Analisis Laporan Keuangan. Yogyakarta: UPP STIM YKPN.

M. Rizky Langgeng Pradhana, Devi Farah Azizah. 2018. Dampak Penerapan Akuntansi Sumber Daya Manusia Terhadap Kinerja Keuangan ( studi kasus pada PT. Perkebunan Nusantara $X$ ). Universitas Brawijaya. Vol. 62, No. 1, September 2018. Hal. 90-98.

Ni Ketut Aci Astari, Ananta Tungga Atmadja, Nyoman Trisna Herawati. Analisis Penerapan Akuntansi Sumber Daya Manusia Pada RS. Kertha Usada (Buleleng). Vol. 8 No. 2, 2017.

Prof. Dr. Afrizal, M.A. 2017. Metode Penelitian Kualitatif : Depok PT. Rajagrafindo Persada.

Rima Rachmawati. 2006. Analisis Penerapan Akuntansi Sumber Daya Manusia Pada PT. X. Jurnal Bisnis, Menaj, Ekon. Vol. 8, No. 2, November 2006. Hal. 1081-1180.

Riswan, Yolanda Fatrecia. 2014. Analisis Laporan Keuangan Sebagai Dasar dalam Penilian Kinerja Keuangan PT. Budi Satria Wahana Motor. Jurnal Akuntansi dan Keuangan. Vol. 5, No. 1, Maret 2014. Hal. 93-121.

Sri Ningsih. 2001. Perlakuan Akuntansi Sumber Daya Manusia: Assets Sekaligus Investor Bagi Perusahaan. Jurnal Ekonomi dan Investasi. Vol. 2 No. 1, Januari 2001. Hal. 23-26.

Sugiono. 2015. Metode Penelitian Kuantitatif Kualitatif dan $R \&$ D. Bandung: Alfabeta.

Sugiono Arif, Untung Edi. 2016. Panduan Praktis Analisis Laporan Keuangan. Jakarta: PT. Grasindo. 
Sujarweni Wiratna. 2017. Analisi Laporan Keuangan Teori, Aplikasi, dan Hasil Penelitian. Yogyakarta: Pustaka Baru Pers.

Wahyudiono Bambang. 2014. Laporan Keuangan memahami Laporan Keuangan perusahaan bagi Manajer, Pengawas / Komisaris, Calon Investor, Kreditur, dan Mahsiswa Bidang Keuangan dan Akuntansi. Jakarta: Raih Asa Sukses (Penebar Swadaya Grup).

Warno. 2011. Pencatatan dan Pengakuan Sember Daya Manusia dalam Akuntansi. Jurnal STIE. Vol. 3, No. 2. Juni 2011. Hal. 1-13.

Yunus Fiscal, Desma. 2016. Analisis Simulasi Penerapan Akuntansi Sumber Daya Manusia Terhadap Perbandingan Kinerja Keuangan. Jurnal Akuntansi dan Keuangan. Vol. 7, No. 2. Sepetmber 2016. Hal. 225-240. 